\title{
Current Management of Chronic Myeloid Leukemia with Tyrosine Kinase Inhibitors
}

\section{Kronik Myeloid Lösemi Güncel Tedavisinde Tirozin Kinaz Inhibitörleri}

\author{
İbrahim C. Haznedaroğlu \\ Hacettepe University Medical School, Department of Hematology, Ankara, Turkey
}

\begin{abstract}
:
The clinical outcomes and survival of tyrosine kinase inhibitor (TKI)-treated patients with chronic myeloid leukemia (CML) have been significantly improved. The aim of this editorial is to outline critical steps of TKI administration practices during the long-term clinical course of CML based on data obtained from randomized clinical trials and international recommendations. The efficacy of TKI treatment, TKI side effects, off-target complications, and long-term morbidities due to both the disease and the drug are common arguments in the management of CML. Complete hematological response, early complete cytogenetic response, faster major molecular response, and deeper, more durable molecular responses (MR4, MR4.5, MR5) are the ultimate goals for TKI-receiving patients with CML.
\end{abstract}

Key Words: Chronic myeloid leukemia, Tyrosine kinase inhibitor, Imatinib, Nilotinib, Dasatinib, Bosutinib, Ponatinib

\section{Özet:}

Kronik myeloid lösemi (KML) tedavisinde tirozin kinaz inhibitörü (TKI) grubu ilaçların kullanımı klinik gidişi ve hastaların yaşam süresini son derece olumlu etkilemiştir. Bu yazının amacı, KML'nin uzun klinik seyri boyunca yapılan TKI uygulamalarının kritik basamaklarını randomize klinik çalışma verileri ve uluslararası rehberler ışı̆̆ında irdelemektir. KML yönetiminde TKI tedavisinin etkinliği, TKI yan etkileri, ilaçların hedef-dışı komplikasyonları, ve hem hastalık seyrine hem de uygulanan ilaçlara bağlı uzun dönem morbiditeler önemli tartışma noktalarını teşkil etmektedir. Tam hematolojik yanıt, erken tam sitogenetik yanıt, daha çabuk gelişen, daha derin (MR4, MR4.5, MR5), ve dayanıklı major moleküler yanıtlar TKI tedavisi alan KML hastalarında klinik seyir boyunca ulaşılması gereken hedefler konumundadırlar.

Anahtar Kelimeler: Kronik myeloid lösemi, Tirozin kinaz inhibitörü, Imatinib, Nilotinib, Dasatinib, Bosutinib, Ponatinib

\section{Introduction}

Current initial frontline therapy for chronic myeloid leukemia (CML) is chronic oral administration of tyrosine kinase inhibitor (TKI) [1,2]. During the last decade, the introduction of TKI to the treatment regimen of CML has significantly affected the survival of patients. Imatinib mesylate was the first TKI in the clinic. The survival benefit of imatinib in CML is excellent [3]. Next-generation TKIs, namely dasatinib [4,5], nilotinib [6], bosutinib [7], and ponatinib [8], were then developed for the management of CML patients. The clinical outcomes and survival of tyrosine kinase inhibitor (TKI)-treated patients with chronic myeloid leukemia (CML) have been significantly improved. The proper clinical and laboratory monitoring of CML patients

Address for Correspondence: İbrahim C. HAZNEDAROĞLU, M.D.,

Hacettepe University Medical School, Department of Hematology, Ankara, Turkey

E-mail: ichaznedaroglu@gmail.com 
Table 1. European LeukemiaNet (ELN) 2013 recommendations for the clinical decision making in the chronic myeloid leukemia $(\mathrm{CM}) \mathrm{L}$ patients receiving tyrosine kinase inhibitor (TKI) based on the response status during the follow-up and monitoring.

RESPONSE STATUS TO TKI BASED ON ELN 2013

OPTIMAL RESPONSE TO THE TKI TREATMENT

FAILURE OF THE CURRENT TKI TREATMENT

WARNING (PREVIOUSLY SUBOPTIMAL RESPONSE) FOR THE CURRENT TKI

TREATMENT
MANAGEMIENT IN THE PATIENT WITH CMI

THERE IS NO INDICATION THAT A CHANGE OF THERAPY MAY IMPROVE SIGNIFICANTLY THE OUTCOME (SURVIVAL)

THE RISK OF THE PROGRESSION AND DEATH FROM LEUKEMIA IS SIGNIFICANT. THE PATIENT SHOULD RECEIVE A DIFFERENT TREATMENT, WHENEVER AVAILABLE AND APPLICABLE

THE CHARACTERISTICS OF THE DISEASE AND THE RESPONSE TO TREATMENT REQUIRE A MORE CAREFUL AND MORE FREQUENT MONITORING, THAT IS TO SAY A MOLECULAR AND A CYTOGENETIC TEST WITHIN LESS THAN 3 MONTHS, AND A MUTATIONAL ANALYSIS. is absolutely necessary to reach those successful outcomes $[9,10,11]$. Complete hematological response (CHR), early complete cytogenetic response (CCyR), faster major molecular response (MMR), and deeper, more durable molecular responses (MR4, MR4.5, MR5) are the ultimate goals for TKI-receiving patients with CML [12]. During the era of 3rd generation TKIs, excellent molecular responses are the most important targets in CML. The surrogate markers of CML outcome (rate, depth, and time to cytogenetic and molecular response) are vital in the clinical management of the disease $[1,13,14,15,16,17]$.

Critical evaluations of CML patients to hit those targets should be made at the baseline and at the $3^{\text {rd }}, 6^{\text {th }}, 12^{\text {th }}, 18^{\text {th }}$, and 24th months after TKI administration. The treatment milestones are checked during the time-line of evaluation [12]. Therapeutic expectations have increased in the field of $\mathrm{CML}$. The functional cure of the disease is now possible with TKIs. Likewise, the molecular responses of MR4 or MR4.5 could lead to the discontinuation of the drug with proper molecular monitoring (TFR; treatment-free remission) within the context of clinical trials [18]. On the other hand, disease progression (accelerated phase (AP) CML or blastic crisis (BC)) under TKI is a great disaster $[19,20,21]$. Survival after progression into AP/BC is still significantly shorter, even in the TKI era. However, the risk of progression has been decreased with the introduction of more powerful TKIs $[22,23,24]$. Major attention should be given for the prevention of disease progression, particularly for the treatment-nave CML or TKI-refractory diseases. Clinical response, the depth of response, and the impact of TKI use on the disease outcome should always be the focuses during the long-term management of CML [12].

Investigational efforts tried to improve the results of $\mathrm{CML}$ first-line therapy of imatinib obtained from the International
Randomized Study of Interferon and STI571 trials. Those attempts included imatinib dose increase, particularly in high-Sokal risk patients [25]; imatinib-based combinations [26]; and the setting of second-generation TKIs as first-line therapy $[24,27]$. Dose optimization studies of TKI, such as the German CML IV [28] and TIDEL [29], have been taken into account for increments in safety, efficacy, tolerability, adherence, and acceptably manageable drug toxicity. The aim of this review is to outline critical steps of TKI administration practices during the long-term clinical course of CML based on data obtained from randomized clinical trials (RCTs) and international recommendations. The efficacy of TKI treatment, TKI side effects, off-target complications, and long-term morbidities due to both the disease and the drug are common arguments in the management of CML. Standardized definitions of molecular response in CML under TKI have been given by the European LeukemiaNet (ELN). MR4 is achieved with a BCR-ABL expression of $<0.01 \%$, MR4.5 with $<0.0032 \%$ BCR-ABLIS, and MR5 with $<0.001 \%$ BCR-ABLIS [28].

\section{Baseline Evaluation and Management of the}

\section{Patient with CML}

Standard baseline evaluation of the de novo CML patient includes exact medical diagnosis of CML, basic laboratory evaluation covering complete blood count (CBC) [30] and peripheral blood smear (PBS), bone marrow histopathology, conventional cytogenetics and/or FISH analyses for the $\mathrm{Ph}^{*}$ chromosome, and quantitative molecular analyses for BCRABLl. Tumor load and disease phase should be defined [12]. Newly diagnosed chronic-phase CML patients should be stratified based on the Sokal [31], Euro/Hasford [32], and EUTOS [33] CML prognostic scoring systems. Novel recent investigations for de novo CML patients have examined the validity of gene expression profiling, genetic polymorphisms, 
next-generation genomics, multidrug resistance genes (MDR, OCT1), fusion transcripts, and preexisting BCR-ABL kinase domain mutations [34,35,36,37,38,39,40,41,42,43].

Current initial TKI treatment for chronic-phase CML is imatinib at $400 \mathrm{mg}$ p.o. [12]. Second-generation TKIs, namely dasatinib at $100 \mathrm{mg}$ p.o. [27] and nilotinib at 600 mg p.o. [24], have also been registered for the first-line therapy of CML. There is a tendency for the prescription of more powerful TKIs in high-Sokal risk CML patients and high-risk patients with complex karyotypic abnormalities at the beginning of the disease for the prevention of disease progression. Likewise, young and low prognostic risk CML patients are candidates for second-generation TKIs for the sake of drug discontinuation in the future. However, heterogeneous presentation and course of CML, individual characteristics, compliance and preferences of the patients, comorbidities, different toxicity profiles of the drugs, and the physician-clinical center experience must all be considered during the initial decision making for first-line TKI usage in newly diagnosed chronic-phase CML [12,24,27].

Evaluation and Management at the 3rd Month after the

\section{Initiation of TKI in the Patient with CML}

Standard disease assessments at the 3rd month of oral TKI administration for the chronic-phase CML patient include critical clinical evaluation and CBC/PBS to reveal CHR, cytogenetic analyses to evaluate the cytogenetic response, and quantitative molecular BCR-ABL analyses to identify molecular response [12]. Optimal response at the 3rd month of imatinib administration is CHR and minor cytogenetic response. However, particularly after the introduction of the powerful second-generation TKIs, namely nilotinib and dasatinib, to the first-line therapy of CML, the expectations in response become higher. Recent RCT studies $[24,27,44,45,46,47,48,49,50]$ indicated that the critical BCR-ABL transcript level (10\% cut-off value) the 3rd month following the start of TKI treatment may have prognostic significance in patients with CML. This scientific observation has been made with imatinib in GIMEMA [44], German CML IV [26], Hammersmith [51], DASISION [52], and ENESTnd [22] trials, and with dasatinib in DASISION [49] and with nilotinib in ENESTnd [22] trials. Challenges for the widespread routine use of the $10 \%$ BCR-ABL transcript cut-off at the 3rd month of TKI are present. First, the estimated ratio of BCR-ABL/ABL is highly technique-dependant. Many laboratories in the world are still not qualified for the international harmonization of scale (IS). High ratio values on the IS scale, house-keeping control gene problems, variations in samples, delays in the exact molecular assessment time after TKI administration, and early unexpected variation kinetics of response in indivi dual CML patients complicate the universal application of the $10 \%$ BCR-ABL transcript cut-off at the 3 rd month of TKI. Furthermore, the tumor burden at diagnosis, prognostic scoring, gene profile, cytoreduction with TKI dosage, treatment adherence, and numerous confounding effects may obscure the real-life picture at the $3^{\text {rd }}$ month of TKI usage outside clinical trials. Nevertheless, any CML patient that does have a BCR-ABL over $10 \%$ after 3 months of TKI presents a strong warning, requiring more careful and more frequent monitoring based on the clear RCT data. If the CML patient exhibits no CHR and/or no minor cytogenetic response, the failure of the first-line TKI is evident. If the initial failed TKI treatment for CML was imatinib, then nilotinib or dasatinib should be given. If 1 of the 2 secondgeneration TKIs (nilotinib or dasatinib) was used as the firstline therapy and failed, the other (dasatinib or nilotinib) could be administered particularly based on the mutation data. During the treatment decision for 2nd line TKIs, a mutational analysis shall be performed. Increasing the dose of imatinib has been tried in the literature but seems to be a dying practice in the era of stronger TKIs. Drug tolerability and adherence to the treatment should always be sought. Effective management of the treatment-related adverse effects is a vital part of the CML care [12].

Evaluation and Management at the $6^{\text {th }}$ Month after the

\section{Initiation of TKI in the Patient with CML}

Standard disease assessments at the 6th month of oral TKI administration for the chronic-phase CML patient include critical clinical evaluation to establish CHR, cytogenetic analyses to evaluate the cytogenetic response, and quantitative molecular BCR-ABL analyses to identify molecular response. Optimal response at the 6th month of imatinib is at least partial cytogenetic response $\left(\mathrm{Ph}^{*}\right.$ chromosome lower than 35\%) [12]. However, particularly after the introduction of the powerful second-generation TKIs, namely nilotinib and dasatinib, to the first-line therapy of CML, the expectations in response become higher. CCyR at 6 months and/or BCR-ABL below 1\% following 6 months of second-generation TKIs are considered as optimal. Any CML patient that does have a BCR-ABL over $10 \%$ and/or $\mathrm{Ph}^{*}$ chromosome over 35\% after 6 months of TKI treatment (particularly nilotinib and dasatinib) may be accepted as a failed case and the treatment strategy may be changed. Those higher treatment milestones could be applied to the first-line imatinib-receiving CML patients and a switch to secondgeneration TKIs may be performed. Cumulative incidence of MMR is higher with both nilotinib and dasatinib. An early switch from imatinib to a second-generation TKI is rational since RCTs have indicated the higher probability of obtaining better responses as well as progression-free survival and overall survival [24,27]. Prevention of disease progression seems to be better achieved with more powerful second-generation TKIs. Specific long-term drug adverse effects (such as pleuropulmonary syndrome for dasatinib and metabolic syndrome for nilotinib), as well as increased treatment costs, should be considered. Drug tolerability and adherence to the treatment should always be sought [12]. 
Evaluation and Management at the $12^{\text {th }}$ Month after the Initiation of TKI in the Patient with CML

Standard disease assessments at the $12^{\text {th }}$ month of oral TKI administration for the chronic-phase CML patient include critical clinical evaluation to establish CHR, cytogenetic analyses to examine the cytogenetic response, and quantitative molecular BCR-ABL analyses to identify molecular response [12]. Additional karyotypic abnormalities should be searched in the BM cytogenetics. Optimal response at the $12^{\text {th }}$ month of imatinib usage is at least CCyR. However, particularly after the introduction of the powerful second-generation TKIs, to the first-line therapy of CML, the expectations in response become higher $\quad[1,6,8,15,16,22,28,44,45,48,50,51,53,54,55,56$, $57,58,59,60,61,62,63]$. CCyR at 12 months and BCR-ABL below $0.1 \%$ following 6 months of second-generation TKIs are considered as optimal based on international guidelines. Any CML patient that does have a BCR-ABL over $1 \%$ and/ or $\mathrm{Ph}^{*}$ chromosome over $1 \%$ after 12 months of TKI usage (particularly nilotinib and dasatinib) may be accepted as a failed case and the treatment strategy may be changed. Those higher treatment milestones could be applied to the first-line imatinib-receiving CML patients and a switch to second-generation TKIs may be performed. Drug tolerability and adherence to the treatment should always be sought [12].

\section{Evaluation and Management at the $18^{\text {th }}$ Month after}

\section{the Initiation of TKI in the Patient with CML}

Standard disease assessments at the 18th month of oral TKI administration for the chronic-phase CML patient include critical clinical evaluation to establish CHR and CCyR, and quantitative molecular BCR-ABL analyses to identify molecular response [12]. Optimal response at the 18th month of imatinib is at least MMR. However, particularly after the introduction of the powerful secondgeneration TKIs, namely nilotinib and dasatinib, to the first-line therapy of CML, the expectations in response become higher $[1,4,6,10,11,17,23,38,39,42,44,45,47,48,4$ $9,50,51,52,53,54,55,56,57]$. CCyR at 18 months and BCRABL below $0.1 \%$ following 18 months of second-generation TKIs are considered as optimal. Any CML patient that does have a BCR-ABL over $1 \%$ and/or $\mathrm{Ph}^{*}$ chromosome over 1\% (absence of CCyR) after 18 months of TKI usage (particularly nilotinib and dasatinib) may be accepted as a failed case and the treatment strategy may be changed [15]. Those higher treatment milestones could be applied to the first-line imatinib-receiving CML patients and a switch to second-generation TKIs may be performed. Drug tolerability and adherence to the treatment should always be sought [12].

\section{Evaluation and Management at the 24th Month and} Thereafter Following the Initiation of TKI in the Patient with CML

Standard disease assessments at the 24th month of oral TKI administration for the chronic-phase CML patient include critical clinical evaluation to establish CHR and CCyR, and quantitative molecular BCR-ABL analyses to identify molecular response [12]. Optimal response at the 24th month of imatinib is at least the continuation of MMR. However, particularly after the introduction of the powerful second-generation TKIs, namely nilotinib and dasatinib, to the first-line therapy of CML, the expectations in response become higher. CCyR at 24 months and BCR-ABL below $0.1 \%$ following 24 months of second-generation TKIs are considered as optimal. Any CML patient that does have a BCR-ABL over $1 \%$ and/or $\mathrm{Ph}^{*}$ chromosome over $1 \%$ after 24 months of TKI usage (particularly nilotinib and dasatinib) may be accepted as a failed case and the treatment strategy may be changed [15]. Those higher treatment milestones could be applied to the first-line imatinib-receiving CML patients and a switch to second-generation TKIs may be performed. Drug tolerability and adherence to the treatment should always be sought. Quality of life is especially a matter of concern in CML patients receiving long-term, maybe lifetime, TKI drugs [12].

In the case of intolerance to any TKIs and/or multi-TKIresistant CML cases with or without mutations, third-line treatment includes bosutinib, ponatinib, allogeneic stem cell transplantation, and experimental therapies [64-66]. ABL domain mutations leading to the increments in the BCRABL oncogenicity may be detected during the TKI therapy. The TKI regimen may be altered with another TKI based on the type of the mutation. Sometimes the entire treatment strategy of CML has to be changed because of the presence of the ABL domain mutation. For instance, T315I is a unique mutation making the CML patient irresponsive to most TKIs (excluding ponatinib) and leads allografting to become an option in the case [15]. Combination treatments such as TKI plus interferon [67] are still a matter of research and are rarely used outside of clinical trials.

Evaluation for the discontinuation of TKIs in the superior TKI-responder patient with CML should be performed in the long term, for instance after 2 years. Patients with deeper molecular responses (MR4, MR4.5, MR5) are candidates for TKI discontinuation [68]. MR4 is achieved with a BCR-ABL expression of $<0.01 \%$, MR 4.5 with $<0.0032 \%$ BCR-ABLIS, and MR5 with $<0.001 \%$ BCR-ABLIS $[28,46]$. Treatment-free remissions and re-induction of the remission with the same TKI seem to be possible based on the data from the STIM trial [68]. Pregnancy represents a cause for TKI discontinuation because of the negative impact of any TKI on organogenesis. 
Patients with AP/BC CML should be treated with the most powerful TKI available and multi-agent chemotherapy before allografting $[19,20,21,65,69,70,71]$. Since those patients with advanced-phase CML still do have a worse prognosis, prevention of disease progression is the most significant aspect of CML disease management.

\section{Future Perspectives of CML}

ELN 2013 recommendations have established how to proceed in clinical decision making in the CML patients receiving TKIs based on the response status (Table 1). 72 The future of CML and TKI treatment will reveal better understandings of the disease pathobiology, leukemic stem cells, signal transduction, and their translations to the patient's care $[34,35,36,37,38,39,40,41,42,43]$. Cure of CML and the eradication of minimal residual disease via the multi-hit drugs with distinct biological actions would be possible. The cessation of therapy with the aim of cure, stem cell depletion, stem cell exhaustion, and immunological control of the disease may be the future strategies in the management of CML.

\section{Conflict of Interest Statement}

The authors of this paper have no conflicts of interest, including specific financial interests, relationships, and/ or affiliations relevant to the subject matter or materials included.

\section{References}

1. Ferdinand R, Mitchell SA, Batson S, Tumur I. Treatments for chronic myeloid leukemia: a qualitative systematic review. J Blood Med 2012;3:51-76.

2. Koca E, Haznedaroğlu İC. Imatinib mesylate and the management of chronic myeloid leukemia (CML). Turk J Haematol 2005;22:161-172.

3. Anstrom KJ, Reed SD, Allen AS, Glendenning GA, Schulman KA. Long-term survival estimates for imatinib versus interferon-alpha plus low-dose cytarabine for patients with newly diagnosed chronic-phase chronic myeloid leukemia. Cancer 2004;101:2584-2592.

4. Kantarjian H, Pasquini R, Hamerschlak N, Rousselot P, Holowiecki J, Jootar S, Robak T, Khoroshko N, Masszi T, Skotnicki A, Hellmann A, Zaritsky A, Golenkov A, Radich J, Hughes T, Countouriotis A, Shah N. Dasatinib or high-dose imatinib for chronic-phase chronic myeloid leukemia after failure of first-line imatinib: a randomized phase 2 trial. Blood 2007;109:5143-5150.

5. Saydam G, Haznedaroglu IC, Temiz Y, Soysal T, Sucak G, Tombuloglu M, Ozdogu H, Yavuz S, Altintas A, Ozet G, Gulbas Z, Ferhanoglu B, Ilhan O. Retrospective evaluation of patients treated with dasatinib for Philadelphia positive leukemias: Turkish experience of 16 months. UHOD 2009;19:195-204.
6. Luciano L, Seneca E, Annunziata M, Pezzullo L, Danise P, Palmieri F, Iovine M, Vallone R, Pane F. Efficacy of nilotinib in early chronic phase CML patients who have suboptimal cytogenetic or molecular response to imatinib. A multicentric retrospective study. ASH Annual Meeting Abstracts 2012;120:4454.

7. Cortes JE, Khoury HJ, Lipton JH, Gambacorti-Passerini C, Brümmendorf TH, Kim DW, Leip E, Kelly V, Besson N, Turnbull K, Kantarjian HM. Baseline predictors of response to bosutinib in patients with chronic phase chronic myeloid leukemia following resistance or intolerance to imatinib plus dasatinib and/or nilotinib. ASH Annual Meeting Abstracts 2012;120:2793.

8. Hochhaus A, Kim DW, Pinilla-Ibarz J, le Coutre P, Paquette R, Chuah C, Nicolini FE, Apperley J, Khoury HJ, Talpaz M, DiPersio JF, DeAngelo D, Abruzzese E, Rea D, Baccarani M, Muller MC, Gambacorti-Passerini C, Wong S, Lustgarten S, Rivera VM, Clackson T, Turner CD, Haluska FG, Guilhot F, Deininger MW, Hughes TP, Goldman JM, Shah N, Kantarjian HM, Cortes JE, The PACE Study Group. Molecular responses with ponatinib in patients with Philadelphia chromosome positive $(\mathrm{Ph}+)$ leukemia: results from the PACE trial. ASH Annual Meeting Abstracts 2012;120:3763.

9. Simonsson B, Porkka K, Richter J. Second-generation BCRABL kinase inhibitors in CML. N Engl J Med 2010;363:1673.

10. Haznedaroglu IC, Cetiner M, Ilhan O. The management of chronic myeloid leukemia in the era of second generation tyrosine kinase inhibitors. UHOD 2011;21:1-3.

11. Haznedaroglu IC, Koca E, Aksu S, Goker H, Sayinalp N, Buyukasik Y, Ozcebe OI. The gray-zone concept, suboptimal response to imatinib, shall be removed from the ELN-CML recommendations. UHOD 2010;20(Suppl 1):25-26.

12. Baccarani M, Cortes J, Pane F, Niederwieser D, Saglio G, Apperley J, Cervantes F, Deininger M, Gratwohl A, Guilhot F, Hochhaus A, Horowitz M, Hughes T, Kantarjian H, Larson R, Radich J, Simonsson B, Silver RT, Goldman J, Hehlmann R; European LeukemiaNet. Chronic myeloid leukemia: an update of concepts and management recommendations of European LeukemiaNet. J Clin Oncol 2009;27:6041-6051.

13. Fausel C. Targeted chronic myeloid leukemia therapy: Seeking a cure. Am J Health Syst Pharm 2007;64(Suppl 15):9-15.

14. Fava C, Cortes J. Optimizing first-line therapy for patients with chronic myeloid leukemia. Semin Hematol 2009;46(Suppl 3):5-10.

15. Gora-Tybor J. Emerging therapies in chronic myeloid leukemia. Curr Cancer Drug Targets 2012;12:458-470.

16. Guilhot F, Roy L, Tomowiak C. Current treatment strategies in chronic myeloid leukemia. Curr Opin Hematol 2012;19:102-109. 
17. Jabbour E, Cortes JE, Ghanem H, O’Brien S, Kantarjian HM. Targeted therapy in chronic myeloid leukemia. Expert Rev Anticancer Ther 2008;8:99-110.

18. Benjamini O, Kantarjian HM, Rios MB, Jabbour E, O’Brien S, Jain P, Faderl S, Garcia-Manero G, Ravandi F, Borthakur G, Quintás-Cardama A, Cortes JE. Patient (Pt)-driven discontinuation of tyrosine kinase inhibitor therapy in chronic phase chronic myeloid leukemia (CML) - Single institution experience. ASH Annual Meeting Abstracts 2012;120:3783.

19. Neelakantan P, Milojkovic D, Gerrard G, Foroni L, Apperley J, Szydlo RM, Reid A, Bua M, Rezvani K, Goldman JM, Marin D. Is major molecular response a safe haven against blast crisis in CML patients treated with imatinib? ASH Annual Meeting Abstracts 2012;120:3760.

20. Saglio G, Hochhaus A, Goh YT, Masszi T, Pasquini R, Maloisel F, Erben P, Cortes J, Paquette R, Bradley-Garelik MB, Zhu C, Dombret H. Dasatinib in imatinib-resistant or imatinib-intolerant chronic myeloid leukemia in blast phase after 2 years of follow-up in a phase 3 study: efficacy and tolerability of 140 milligrams once daily and 70 milligrams twice daily. Cancer 2010;116:3852-3861.

21. Uz B, Bektas O, Eliacık E, Goker H, Erbilgin Y, Sayitoglu M, Sayinalp N, Aksu S, Buyukasik Y, Ozcebe O, Haznedaroglu IC. Allografting for Bosutinib, Imatinib, Nilotinib, Dasatinib, and Interferon Resistant Chronic Myeloid Leukemia without ABL Kinase Mutation. Case Rep Hematol 2011;2011:263725.

22. Hochhaus A, Hughes TP, Saglio G, Guilhot F, Al-Ali HK, Rosti G, Nakaseko C, De Souza CA, Kemp C, Fan X, Hoenekopp A, Larson RA, Kantarjian HM. Outcome of patients with chronic myeloid leukemia in chronic phase (CML-CP) based on early molecular response and factors associated with early response: 4-year follow-up data from ENESTnd (Evaluating Nilotinib Efficacy and Safety in Clinical Trials Newly Diagnosed Patients). ASH Annual Meeting Abstracts 2012;120:167.

23. Kantarjian HM, Shah NP, Cortes JE, Baccarani M, Agarwal MB, Undurraga MS, Wang J, Ipiña JJ, Kim DW, Ogura M, Pavlovsky C, Junghanss C, Milone JH, Nicolini FE, Robak T, Van Droogenbroeck J, Vellenga E, Bradley-Garelik MB, Zhu C, Hochhaus A. Dasatinib or imatinib in newly diagnosed chronic-phase chronic myeloid leukemia: 2-year followup from a randomized phase 3 trial (DASISION). Blood 2012;119:1123-1129.

24. Saglio G, Kim DW, Issaragrisil S, le Coutre P, Etienne G, Lobo C, Pasquini R, Clark RE, Hochhaus A, Hughes TP, Gallagher N, Hoenekopp A, Dong M, Haque A, Larson RA, Kantarjian HM; ENESTnd InvestigatorsNilotinib versus imatinib for newly diagnosed chronic myeloid leukemia. N Engl J Med 2010;362:2251-2259.
25. Baccarani M, Rosti G, Castagnetti F, Haznedaroglu I, Porkka K, Abruzzese E, Alimena G, Ehrencrona H, Hjorth-Hansen H, Kairisto V, Levato L, Martinelli G, Nagler A, Lanng Nielsen J, Ozbek U, Palandri F, Palmieri F, Pane F, RegeCambrin G, Russo D, Specchia G, Testoni N, Weiss-Bjerrum O, Saglio G, Simonsson B. Comparison of imatinib 400 $\mathrm{mg}$ and $800 \mathrm{mg}$ daily in the front-line treatment of highrisk, Philadelphia-positive chronic myeloid leukemia: a European LeukemiaNet Study. Blood 2009;113:4497-4504.

26. Berger U, Engelich G, Reiter A, Hochhaus A, Hehlmann R; German CML Study Group. Imatinib and beyond--the new CML study IV. A randomized controlled comparison of imatinib vs imatinib/interferon-alpha vs imatinib/lowdose AraC vs imatinib after interferon-alpha failure in newly diagnosed chronic phase chronic myeloid leukemia. Ann Hematol 2004;83:258-264.

27. Kantarjian H, Shah NP, Hochhaus A, Cortes J, Shah S, Ayala M, Moiraghi B, Shen Z, Mayer J, Pasquini R, Nakamae H, Huguet F, Boqué C, Chuah C, Bleickardt E, Bradley-Garelik MB, Zhu C, Szatrowski T, Shapiro D, Baccarani M. Dasatinib versus imatinib in newly diagnosed chronic-phase chronic myeloid leukemia. N Engl J Med 2010;362:2260-2270.

28. Hanfstein B, Müller MC, Hehlmann R, Erben P, Lauseker M, Fabarius A, Schnittger S, Haferlach C, Göhring G, Proetel U, Kolb HJ, Krause SW, Hofmann WK, Schubert J, Einsele H, Dengler J, Hänel M, Falge C, Kanz L, Neubauer A, Kneba M, Stegelmann F, Pfreundschuh M, Waller CF, Branford S, Hughes TP, Spiekermann K, Baerlocher GM, Pfirrmann M, Hasford J, Saußele S, Hochhaus A; SAKK; German CML Study Group). Leukemia 2012;26:2096-2102.

29. Yeung DT, Osborn MP, White DL, Branford S, Kornhauser M, Slader C, Issa S, Hiwase DK, Hertzberg MS, Schwarer AP, Filshie R, Arthur CK, Kwan YL, Forsyth CJ, Ross R, Mills AK, Grigg A, Hughes TP; on Behalf Of ALLG. Early switch to nilotinib does not overcome the adverse outcome for CML patients failing to achieve early molecular response on imatinib, despite excellent overall outcomes in the TIDEL II Trial. ASH Annual Meeting Abstracts 2012;120:3771.

30. Hayran M, Koca E, Haznedaroglu IC, Unsal I, Durgun B, Guvenc F, Ozturk B, Ratip S, Ozcebe OI. Predicting chronic leukaemias from assessment of complete peripheral blood counts. J Intl Med Res 2006;34:640-647.

31. Sokal JE, Cox EB, Baccarani M, Tura S, Gomez GA, Robertson JE, Tso CY, Braun TJ, Clarkson BD, Cervantes F, et al. Prognostic discrimination in "good-risk" chronic granulocytic leukemia. Blood 1984;63:789-799.

32. Hasford J, Pfirrmann M, Hehlmann R, Allan NC, Baccarani M, Kluin-Nelemans JC, Alimena G, Steegmann JL, Ansari H. A new prognostic score for survival of patients with chronic myeloid leukemia treated with interferon alfa. Writing Committee for the Collaborative CML Prognostic Factors Project Group. J Natl Cancer Inst 1998;90:850-858. 
33. Hasford J, Baccarani M, Hoffmann V, Guilhot J, Saussele S, Rosti G, Guilhot F, Porkka K, Ossenkoppele G, Lindoerfer D, Simonsson B, Pfirrmann M, Hehlmann R. Predicting complete cytogenetic response and subsequent progressionfree survival in 2060 patients with CML on imatinib treatment: the EUTOS score. Blood 2011;118:686-692.

34. Bourgne C, Janel A, Chassagne J, Rapatel C, Tournilhac O, Guerci A, Lioret F, Briançon A, Berger J, Bamdad M, BoiretDupré N, Berger MG. Phosphorylation of spleen tyrosine kinase (Syk) appears to be related to the blast phase of chronic myeloid leukemia. ASH Annual Meeting Abstracts 2012;120:4425.

35. Gutknecht M, Joas S, Güttler L, Kanz L, Salih HR, Grünebach F, Rittig SM. Monocyte-derived dendritic cells induce functionally active regulatory $\mathrm{T}$ cells upon exposure to BCR-ABL tyrosine kinase inhibitors. ASH Annual Meeting Abstracts 2012;120:2156.

36. Gutknecht M, Joas S, Kanz L, Salih HR, Rittig SM, Gruenebach F. Inhibition of PI3K/Akt and Erk signaling pathways by BCR-ABL tyrosine kinase inhibitors upregulates the immunosuppressive receptor osteoactivin in monocyte-derived dendritic cells. ASH Annual Meeting Abstracts 2012;120:1050.

37. Nievergall E, White DL, Yong ASM, Ramshaw HS, Busfield SJ, Vairo G, Lopez AF, Hughes TP, Hiwase DK. Effective elimination of CML progenitor and stem cells through combination of \{alpha\}-CD123 antibody-dependent cell-mediated cytotoxicity and tyrosine kinase inhibitor treatment. ASH Annual Meeting Abstracts 2012;120:32.

38. Quintarelli C, De Angelis B, Errichiello S, Caruso S, Esposito N, Luciano L, Paratore S, Galimberti C, Soverini S, Terragna C, Cilloni D, Saglio G, Martinelli G, Giles F, Hochhaus A, Pane F. Analysis of bone marrow microenvironment factors as early markers of response in patients with newly diagnosed Bcr-Abl positive CML in chronic phase treated with nilotinib. ASH Annual Meeting Abstracts 2012;120:2795.

39. Rothe K, Lin KBL, Lin H, Leung A, Forrest DL, Gorski $\mathrm{S}$, Jiang $\mathrm{X}$. Identification of a unique autophagy gene expression signature in CD34+CML stem/progenitor cells that correlates with clinical response to imatinib mesylate. ASH Annual Meeting Abstracts 2012;120:1662.

40. Schafranek L, Nievergall E, Powell JA, Hiwase DK, White DL, Hughes TP. Commitment of CML cells to apoptotic cell death depends on the length of exposure to Das and the level of STAT5 activity. ASH Annual Meeting Abstracts 2012;120:3736.

41. Schemionek M, Steidl U, Schwab A, Tenen DG, Mhairi C, Holyoake TL, Preisinger C, Mueller-Tidow C, Brümmendorf TH, Koschmieder S. Metastasis suppressor
1 is downregulated in CML stem cells and overexpression impairs early leukemic cell propagation. ASH Annual Meeting Abstracts 2012;120:2776.

42. Slupianek A, Falinski R, Znojek P, Stoklosa T, Flis S, Doneddu V, Synowiec E, Blasiak J, Bellacosa A, Skorski T. BCR-ABLl kinase inhibits DNA glycosylases to enhance oxidative DNA damage and stimulate genomic instability. ASH Annual Meeting Abstracts 2012;120:520.

43. Tabe Y, Jin L, Iwanami H, Kazuno S, Fujimura T, Matsushita H, Ueno T, Miida T, Andreeff M, Konopleva M, Kimura S. Analysis of dasatinib-induced molecular mechanisms of apoptosis in hypoxia-adopted CML cells utilizing quantitative proteomics technology. ASH Annual Meeting Abstracts 2012;120:2773.

44. Castagnetti F, Gugliotta G, Breccia M, Specchia G, Abruzzese E, Levato L, Cavazzini F, Iurlo A, Stagno F, Ferrero D, Porretto F, Martino B, Rupoli S, Intermesoli T, Fava C, Palandri F, Venturi C, Soverini S, Testoni N, Alimena G, Pane F, Saglio G, Martinelli G, Baccarani M, Rosti G. The BCR-ABL transcript levels at 3 and 6 months predict the long-term outcome of chronic myeloid leukemia patients treated frontline with imatinib mesylate: a Gimema CML WP analysis. ASH Annual Meeting Abstracts 2012;120:1678.

45. Gugliotta G, Castagnetti F, Palandri F, Breccia M, Levato L, Stagno F, Rege-Cambrin G, Zaccaria A, Specchia G, Usala E, Gozzini A, Martino B, Capucci A, Musto P, Tiribelli M, Abruzzese E, Soverini S, Bochicchio MT, Testoni N, Saglio G, Martinelli G, Pane F, Alimena G, Baccarani M, Rosti G. Cytogenetic and molecular responses at 3 months are associated with a better outcome in early chronic phase (ECP) chronic myeloid leukemia (CML) patients treated with nilotinib. ASH Annual Meeting Abstracts 2012;120:2797.

46. Hughes TP, Hochhaus A, Branford S, Müller MC, Kaeda JS, Foroni L, Druker BJ, Guilhot F, Larson RA, O'Brien SG, Rudoltz MS, Mone M, Wehrle E, Modur V, Goldman JM, Radich JP; IRIS investigators. Long-term prognostic significance of early molecular response to imatinib in newly diagnosed chronic myeloid leukemia: an analysis from the International Randomized Study of Interferon and STI571 (IRIS). Blood 2010;116:3758-3765.

47. Jain P, Kantarjian HM, Nazha A, Jabbour E, QuintásCardama A, Benjamini O, Pierce SA, Cardenas-Turanzas M, Verstovsek S, Borthakur G, Ravandi F, O'Brien S, Cortes JE. Early molecular and cytogenetic responses predicts for significantly longer event free survival (EFS) and overall survival (OS) in patients (pts) with newly diagnosed chronic myeloid leukemia (CML) in chronic phase (CP) - an analysis of 4 tyrosine kinase inhibitor (TKI) modalities (standard dose imatinib, high dose imatinib, dasatinib and nilotinib). ASH Annual Meeting Abstracts 2012;120:70. 
48. Kim DDH, Lee HG, Kamel-Reid S, Lipton JH. BCR/ABL transcript at 3 months predicts long-term outcomes following second generation tyrosine kinase inhibitor therapy in the patients with CML in chronic phase who failed imatinib. ASH Annual Meeting Abstracts 2012;120:2777.

49. Saglio G, Kantarjian HM, Shah N, Jabbour EJ, QuintasCardama A, Steegmann JL, Boqué C, Chuah C, Pavlovsky C, Mayer J, Ukropec J, Wildgust M, Hochhaus A. Early response (molecular and cytogenetic) and long-term outcomes in newly diagnosed chronic myeloid leukemia in chronic phase (CML-CP): exploratory analysis of DASISION 3-year data. ASH Annual Meeting Abstracts 2012;120:1675.

50. White DL, Saunders VA, Yeung DT, Grigg A, Hughes TP. Early molecular response to imatinib in CP-CML patients: the significance of early dose intensity and OCT-1 activity in responders and efficacy of dose escalation and switch to nilotinib in non-responders. ASH Annual Meeting Abstracts 2012;120:693.

51. Marin D, Hedgley C, Clark RE, Apperley J, Foroni L, Milojkovic D, Pocock C, Goldman JM, O’Brien S. Predictive value of early molecular response in patients with chronic myeloid leukemia treated with first-line dasatinib. Blood 2012;120:291-294.

52. Kantarjian H, O’Brien S, Jabbour E, Shan J, Ravandi F, Kadia T, Faderl S, Garcia-Manero G, Borthakur G, Cortes J. Impact of treatment end point definitions on perceived differences in long-term outcome with tyrosine kinase inhibitor therapy in chronic myeloid leukemia. J Clin Oncol 2011;29:3173-3178.

53. Choi SY, Lee SE, Kim SH, Jang EJ, Lee J, Oh YJ, Bang JH, Park JE, Byun JY, Jeon HL, Woodman RC, Szczudlo T, Jootar S, Kim HJ, Sohn SK, Park JS, Kim SH, Zang DY, Oh SJ, Kim DW. Nilotinib versus high-dose imatinib in early chronic phase CML patients who have suboptimal molecular responses to standard-dose imatinib: updated data from RE-Nice Study. ASH Annual Meeting Abstracts 2012;120:3775.

54. Cortes J, Kantarjian H. How I treat newly diagnosed chronic phase CML. Blood 2012;120:1390-1397.

55. Cortes JE, Brümmendorf TH, Khoury HJ, Hochhaus A, Apperley J, O'Brien S, Leip E, Kelly V, Ruffner K, Kantarjian HM. Assessment of early cytogenetic response as a predictor of long-term clinical outcomes in a phase $1 / 2$ study of bosutinib in chronic phase CML. ASH Annual Meeting Abstracts 2012;120:2798.

56. Cortes JE, Pasquini R, Kantarjian HM, Joske D, Meillon LA, Shen Z, Piccolo C, Zernovak O, Sivarathinasami R, Eng DF, Kim DW, Hughes TP. First-line treatment and management of chronic myeloid leukemia (CML) in clinical practice: update of $>1800$ patients (Pts) in the WORLD CML Registry. ASH Annual Meeting Abstracts 2012;120:3750.
57. Falchi L, Kantarjian HM, Quintas-Cardama A, O'Brien S, Jabbour EJ, Ravandi F, Borthakur G, Garcia-Manero G, Verstovsek S, Burger JA, Luthra R, Cortes JE. Clinical significance of deeper molecular responses with four modalities of tyrosine kinase inhibitors as frontline therapy for chronic myeloid leukemia. ASH Annual Meeting Abstracts 2012;120:164.

58. Hughes TP, Lipton JH, Spector N, Leber B, Pasquini R, Clementino N, Schwarer AP, Etienne G, Guerci-Bresler A, Branford S, Purkayastha D, Collins L, Szczudlo T, Cervantes F. Switching to nilotinib is associated with continued deeper molecular responses in CML-CP patients with minimal residual disease after $\geq 2$ years on imatinib: ENESTcmr 2-year follow-up results. ASH Annual Meeting Abstracts 2012;120:694.

59. Larson RA, Hochhaus A, Hughes TP, Clark RE, Etienne G, Kim DW, Flinn IW, Kurokawa M, Moiraghi B, Yu R, Blakesley RE, Gallagher NJ, Saglio G, Kantarjian HM. Leukemia 2012;26:2197-2203.

60. Rosti G, Castagnetti F, Gugliotta G, Palandri F, Baccarani M. Second-generation BCR-ABL inhibitors for frontline treatment of chronic myeloid leukemia in chronic phase. Crit Rev Oncol Hematol 2012;82:159-170.

61. Rosti G, Gugliotta G, Castagnetti F, Breccia M, Levato L, Rege-Cambrin G, Capucci A, Tiribelli M, Zaccaria A, Bocchia M, Stagno F, Cavazzini F, Specchia G, Martino B, Cedrone M, Intermesoli T, Palandri F, Soverini S, Bochicchio MT, Testoni N, Alimena G, Pane F, Saglio G, Martinelli G, Baccarani M. Five-year results of nilotinib $400 \mathrm{mg}$ BID in early chronic phase chronic myeloid leukemia (CML): high rate of deep molecular response - update of the GIMEMA CML WP Trial CML0307. ASH Annual Meeting Abstracts 2012;120:3784.

62. Sail KR, Chen L, Jackson J, Ericson SG, Haislip S, Ibison T, Gilmore J, Saleh MN. Treatment patterns among patients with Philadelphia chromosome positive chronic myeloid leukemia (Ph+ CML) treated with imatinib in a community setting. ASH Annual Meeting Abstracts 2012;120:3179.

63. Wu B, Zhong H, Saglio G, Chen F. Different strategies for firstline treatment of chronic myeloid leukaemia: an economic analysis. ASH Annual Meeting Abstracts 2012;120:4696.

64. Quintás-Cardama A, Kantarjian H, Cortes J. Bosutinib for the treatment of chronic myeloid leukemia in chronic phase. Drugs Today (Barc) 2012;48:177-188.

65. Cortes JE, Kim DW, Pinilla-Ibarz J, le Coutre P, Paquette R, Chuah C, Nicolini FE, Apperley J, Khoury HJ, Talpaz M, DiPersio JF, DeAngelo DJ, Abruzzese E, Rea D, Baccarani M, Muller MC, Gambacorti-Passerini C, Wong S, Lustgarten S, Rivera VM, Clackson T, Turner CD, Haluska FG, Guilhot F, Deininger MW, Hochhaus A, Hughes T, Goldman JM, Shah 
N, Kantarjian HG; The PACE Study Group. A pivotal phase 2 trial of ponatinib in patients with chronic myeloid leukemia (CML) and Philadelphia chromosome-positive acute lymphoblastic leukemia (Ph+ALL) resistant or intolerant to dasatinib or nilotinib, or with the T315I BCR-ABL mutation: 12-month follow-up of the PACE Trial. ASH Annual Meeting Abstracts 2012;120:163.

66. Ahmed S, Saliba RM, De Lima M, Rondon G, Kebriaei P, Fisher TD, Jabbour E, Chen J, Kantarjian H, Anderlini P, Alousi AM, Hosing CM, Andersson B, Jones RB, Qazilbash MH, Shpall EJ, Giralt S, Champlin RE. Sequential treatment after allogeneic stem cell transplantation for chronic myelogenous leukemia. ASH Annual Meeting Abstracts 2012;120:3129.

67. Nicolini FE, Etienne G, Dubruille V, Roy L, Huguet F, Legros L, Giraudier S, Coiteux V, Guerci-Bresler A, Lenain P, Rea D, Ame S, Cony-Makhoul P, Gardembas M, Hermet E, Rousselot P, Gagnieu MC, Morisset S, Pivot C, Etienne M, Guilhot F, Dulucq S, Mahon FX. Pegylated interferon-\{alpha\} $2 \mathrm{a}$ in combination to nilotinib as first line therapy in newly diagnosed chronic phase chronic myelogenous leukemia provides high rates of MR4.5. Preliminary results of a phase II study. ASH Annual Meeting Abstracts 2012;120:166.

68. Mahon FX, Réa D, Guilhot J, Guilhot F, Huguet F, Nicolini F, Legros L, Charbonnier A, Guerci A, Varet B, Etienne G, Reiffers J, Rousselot P; Intergroupe Français des Leucémies Myéloïdes ChroniquesDiscontinuation of imatinib in patients with chronic myeloid leukaemia who have maintained complete molecular remission for at least 2 years: the prospective, multicentre Stop Imatinib (STIM) trial. Lancet Oncol 2010;11:1029-1035.
69. Chae YK, Kantarjian HM, Romo CG, Whitaker C, Jabbour EJ, O'Brien S, Borthakur G, Ravandi F, Thomas DA, Pierce SA, Quintás-Cardama A, Cortes JE. Prognostic factors in the blastic and accelerated phase of patients with chronic myeloid leukemia (CML) in the tyrosine kinase inhibitor (TKI) era. ASH Annual Meeting Abstracts 2012;120:3786.

70. Ghanem H, Kantarjian HM, Jabbour EJ, Cortes JE, QuintasCardama A. Rare blast phase (BP) phenotypes of chronic myeloid leukemia (CML). ASH Annual Meeting Abstracts 2012;120:4434.

71. Strati P, Kantarjian HM, Thomas DA, O'Brien SM, Jabbour EJ, Quintas-Cardama A, Borthakur G, Faderl S, Ravandi F, Cortes JE. Hyper-CVAD plus imatinib or dasatinib for patients with lymphoid blastic phase of chronic myeloid leukemia. ASH Annual Meeting Abstracts 2012;120:3766.

72. Baccarani M, Deininger MW, Rosti G, et al. European LeukemiaNet recommendations for the management of chronic myeloid leukemia: 2013. Blood 2013; 122:872884 . 